Creative Commons User License: CC BY-NC-ND

Abstracted by: EBSCOhost, Electronic Journals Service (EJS),

Google Scholar, Journal Seek, Scientific Commons,

Food and Agricultural Organization (FAO), CABI and Scopus

http://eoi.citefactor.org/10.11226/v26i1
Journal of Agricultural Extension

Vol. 26 (1) January, 2022

ISSN(e): 24086851; ISSN(Print); 1119944X

http://journal.aesonnigeria.org

http://www.ajol.info/index.php/jae

Email: editorinchief@aesonnigeria.org

\title{
Extension-Market Linkages on Banana Commercialisation Among Smallholder Farmers in Meru Region, Kenya
}

https://dx.doi.org/10.4314/jae.v26i1.3

\section{Kirimi, Florence Kaumi}

Department of Agricultural Economics and Extension, University of Embu, Embu, Kenya.

Email: kaumi.florence@embuni.ac.ke, Phone: +254726394686

\section{Onyari, Charles Nyambane}

Department of Water and Agricultural Resource Management, University of Embu, Embu, Kenya. Email: onyari.charles@embuni.ac.ke, Phone: +254721782254.

\section{Njeru, Lucy Karega}

Department of Agricultural Economics, University of Nairobi, Nairobi, Kenya. Email: lucykarega@gmail.com, Phone: +254723594397.

\section{Mogaka, Hezron Rasugu}

Department of Agricultural Economics and Extension, University of Embu, Embu, Kenya. Email: mogaka.hezron@embuni.ac.ke, Phone: +254722325500

\begin{abstract}
The study examined the effect of extension-market linkages on banana commercialisation among smallholder farmers in the Meru region, Kenya. The study sampled 400 farmers from a target population of 288,802 from the Meru region. The Tobit model was used to analyse the effect of extension-market linkages on banana commercialisation. The results revealed that sources of marketing information (Coef. -0.06) had a negative influence on farmers commercialising banana production. The result showed that the reliability of local extension service providers in enabling farmer's access to market information (Coef. 0.04) had a positive influence on farmers commercialising banana production. The findings also showed that users of marketing information in the commercialisation banana business (Coef. 0.63) had a positive influence on farmers commercialising banana production. The study concludes that there was an association between extension marketing linkages and banana commercialization among smallholder farmers in Meru region, Kenya. Government should create and implement more policies that will favour and encourage farmers to commercialise bananas. This will help farmers increase their income.
\end{abstract}

Keywords: Extension-market linkages, banana commercialisation, smallholder farmers. 
Creative Commons User License: CC BY-NC-ND

Abstracted by: EBSCOhost, Electronic Journals Service (EJS),

Google Scholar, Journal Seek, Scientific Commons,

Food and Agricultural Organization (FAO), CABI and Scopus
Journal of Agricultural Extension

Vol. 26 (1) January, 2022

ISSN(e): 24086851; ISSN(Print); 1119944X

http://journal.aesonnigeria.org

http://www.ajol.info/index.php/jae

Email: editorinchief@aesonnigeria.org

\section{Introduction}

To remedy marketing-related challenges, there is a need for capacity building among farmers on the appropriateness of market information sources and appropriate interpretation of such information to spur agricultural profitability (Kassa, Yigezu, \& Alemayehu, 2017). Extension agents need to play the role of motivating the development of farmer marketing groups, which are crucial in aggregating farm produce, price negotiation and farm input acquisition at lower prices. Banana production and commercialisation are pillars of global food security (Tinzaara, Stoian, Ocimati, Kikulwe, Otieno \& Blomm, 2018). There are various problems in the stages of banana production, such as pre-production, production, post-harvest management, and the marketing of bananas. Land, inputs and planting materials are the main hurdles at the pre-production stage. When it comes to enhancing soil fertility, managing pests and diseases and maximizing water, appropriate solutions are essential. After harvest, bananas have obstacles related to transportation, storage, and value addition through the development of products and by-products that take advantage of bananas' genetic diversity. Uncertainty about consumer preferences and trends, and a lack of marketing infrastructure are all contributing factors to marketing issues (Tinzaara et al, 2018).

Kassa et al. (2017) observed that the number of extension contacts significantly affect the extent of farm household's participation in marketing. In a study conducted by Dowsing \& Cardey (2020), on smallholder farmers' perspectives on advisory extension services, they found that participation in the advisory extension services (AES) process mainly involved two modes: consultative, in which advice and services are decided together with the provider, and collaborative, in which input is gathered with other stakeholders and new strategies are implemented. Farmers judged AES performance based on feedback, chronology and relevance. Farmers said that better access to resources such as savings and loans, as well as improved market and on-farm opportunities, would be desirable additions or alternatives to present services. Smallholder farmers, on the other hand, will only be able to combine farming with off-farm operations if they have access to resources like financing and markets. The formation of CBOs/FBOs at the community level could aid in the successful dissemination and scaling of AES, and smallholder farmers' participation in these organizations would aid in adapting services to specific locations. In addition service providers may be able to collaborate more closely with the model or innovative farmers (Dowsing \& Cardey, 2020)

A study by Marcia et al. (2016) in Western Kenya on market barriers pointed to capital access as a major bottleneck to vegetable farming in the region. The study further recommended that policies should target the improvement of capital and infrastructure access to connect rural farmers with urban consumers. However, extension agents' involvement in farmer market access is still inadequate or completely not addressed. 
Creative Commons User License: CC BY-NC-ND

Abstracted by: EBSCOhost, Electronic Journals Service (EJS),

Google Scholar, Journal Seek, Scientific Commons,

Food and Agricultural Organization (FAO), CABI and Scopus

http://eoi.citefactor.org/10.11226/v26i1
Journal of Agricultural Extension

Vol. 26 (1) January, 2022

ISSN(e): 24086851; ISSN(Print); 1119944X

http://journal.aesonnigeria.org

http://www.ajol.info/index.php/jae

Email: editorinchief@aesonnigeria.org

This study, focused on the role of extension service providers in promoting linkages among farmers with the market actors for better banana production in Meru region, Kenya.

\section{Methodology}

The study was conducted in the Meru region, with a latitude and longitude $0^{\circ} 10^{\prime} 0^{\prime \prime}$ South, $37^{\circ} 17^{\prime} 59^{\prime \prime}$ East (Kenya National Bureau of Statistics, 2019).

This study targeted a population of 288,802 smallholder banana farmers' households in the Meru region, respectively (Table 1).

\section{Table 1: Population and sample}

\begin{tabular}{lcc}
\hline County & Target Population & Sample Size \\
\hline Meru County & 269,499 & 370 \\
Tharaka -Nithi County & 19,303 & 30 \\
Total & 288,802 & 400 \\
\hline
\end{tabular}

Tharaka-Nithi County Integrated Development Programme, 2018- 2022; Meru County Integrated Development Programme, 2018- 2022

The sub-county from each of the two counties formed a stratum.

Structured and semi-structured questionnaires were administered face to face to a sample of 400 banana farmers in the Meru region. The Tobit model was used to examine the impact of banana market extension linkages. The model was employed because it was suitable for the duration of time to censor non-participants in the commercialisation of bananas. Tobit views all zero remarks (those that have not sold) as corner solutions in which the household is believed not to have sold bananas at all. The model also predicts that the selling choice and the actual levels of sales will be simultaneously determined by the same variables that also increase the likelihood of selling to the total banana output sold. The decision to participate in banana commercialisation and the intensity of participation was jointly determined. The proportion range between 0 and 1 with 0 being those who did commercialise and 1 being those who would have commercialised. The Tobit model was specified as shown in equations 1,2 and 3

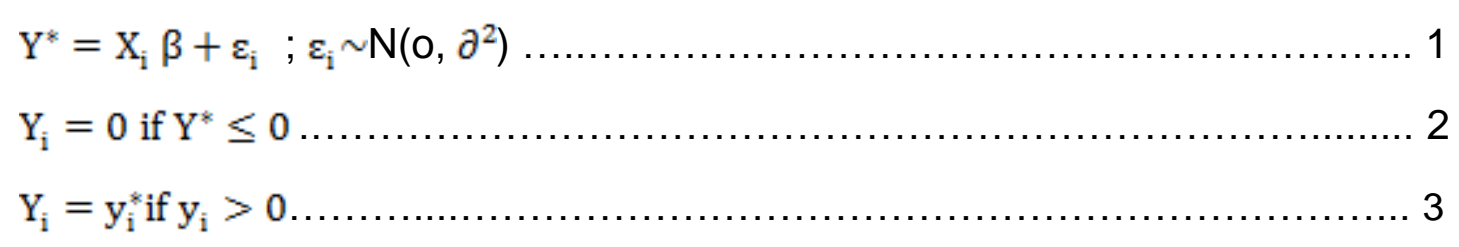

\section{Results and Discussion}

\section{Production Characteristics}

Table 2 shows that more than three-quarters of the respondents $(77.0 \%)$ had land sizes up to two acres set aside for growing bananas while $17.3 \%$ owned between 2 and 4 acres of land for the crop. Only a few (5.7\%) owned land set aside for the crop. These findings imply that the banana growers are small-scale farmers, which in 
Creative Commons User License: CC BY-NC-ND

Abstracted by: EBSCOhost, Electronic Journals Service (EJS),

Google Scholar, Journal Seek, Scientific Commons,

Food and Agricultural Organization (FAO), CABI and Scopus
Journal of Agricultural Extension

Vol. 26 (1) January, 2022

ISSN(e): 24086851; ISSN(Print); 1119944X

http://journal.aesonnigeria.org

http://www.ajol.info/index.php/jae

Email: editorinchief@aesonnigeria.org

itself can limit expanded production and subsequently low farm incomes from the crop. The findings are in line with those of Mwendia (2019) that the majority of Meru County banana producers had very small portions of land sizes, restricting diversification in the research area to large-scale banana cultivation. The main cause of small areas of land in banana cultivation was the large population, which led to the division of land between the beneficiaries of parents' land.

\section{Rate of Banana Production}

Table 2 shows that $71.3 \%$ of the respondents were of the view that the production level of the crop was average while 16.3 and $9.0 \%$ felt that the production rates were high and low respectively. This shows that a great majority (87.6\%) opine that their production levels were above-average and only $9.0 \%$ thought that the production level of the crop was low. It was noted that partly $3.8 \%$ of the respondents were not sure of the level of banana production in their areas. The findings concur with the report of Farmbiz Africa (2019), that smallholder farmers have chosen to produce bananas because of their accessible markets and the additional sources of income.

\section{Variety of Bananas Commonly Grown}

The findings in Table 2 reveal that the most popular variety was the William Hybrid $(32.5 \%)$ followed by Grand Nain $(22.5 \%)$, Giant Cavendish $(21.3 \%)$ and then the local or traditional type $(20.5 \%)$. This shows that the preference for the previous three is relatively more among the farmers although about one third grow more of the William Hybrids due to market demand. The findings are in agreement with those of the Meru County government report (2019) that Meru County is a leading banana producer in the region, Meru has an estimated value of over Ksh.6B, known on research done in 2016, and is known for the production of various varieties of banana, such as William hybrid, gross Mitchel (Kampala), giant cavendish and Uganda vert (Kiganda) as well as plantations. Gichagara is also a popular plant producer (Meru County government report, 2019).

Table 2: Production characteristics

\begin{tabular}{llc} 
Production Characteristics & & $\%$ \\
Rate of Banana Production & High & 16.3 \\
& Average & 71.3 \\
& Low & 12.5 \\
Acreage of Bananas & $0-2$ & 77.0 \\
& $2-4$ & 17.3 \\
Variety of Banana commonly Grown & $4-6$ & 5.7 \\
& William & 32.8 \\
& Hybrids & \\
& Grand Nain & 22.5 \\
& Giant & 21.3 \\
& Cavendish & \\
& Traditional & 20.5 \\
& Others & 3.0 \\
\hline
\end{tabular}


Creative Commons User License: CC BY-NC-ND

Abstracted by: EBSCOhost, Electronic Journals Service (EJS),

Google Scholar, Journal Seek, Scientific Commons,

Food and Agricultural Organization (FAO), CABI and Scopus
Journal of Agricultural Extension

Vol. 26 (1) January, 2022

ISSN(e): 24086851; ISSN(Print); 1119944X

http://journal.aesonnigeria.org

http://www.ajol.info/index.php/jae

Email: editorinchief@aesonnigeria.org

\section{Factors Affecting Banana Commercialisation}

The findings in Table 3 show that several variables influenced banana commercialisation by the farmers. The association between access to market information and banana commercialisation was significant, implying that farmers having information on market information i.e (types of market, market prices, partners/linkages, new markets, existing or changing market policies will influence their decision to commercialise or not commercialise banana farming.

The type of information that the farmers get about banana marketing and banana commercialisation was statistically significant implying that the type of information that the farmers get about banana marketing influences banana commercialisation farmers indicating that the majority of the farmers got information on market prices and types of market. Muchesa, Nkosi, Zwane, \& van Niekerk (2019), found that there was a statistically significant correlation between the number of farmers that receive agricultural marketing information and their average profit. If farmers obtain proper input, training, and extension support, production and food security in Zimbabwe's community regions can be considerably improved. Furthermore, communal farmers can effectively improve income from agriculture enterprises and upgrade communal farmers who originate from the most vulnerable sector of the rural population by establishing market links (Muchesa, Nkosi, Zwane, \& van Niekerk, 2019).

There was no association between the most useful type of information on banana marketing and banana commercialisation (Table 3). This implies that all the information regarding banana marketing was useful to farmers in banana commercialisation. The study also noted that there was no association between Sources of marketing information and banana commercialisation which was not statistically significant. This implies that it does not matter the platform that gives the farmers market information to adopt banana commercialisation. The sources of market information that is extension officers, radio/television, leaflets pamphlets, other farmers, call or text messages and the digital link do not necessarily lead to whether to farmers commercialise banana farming or not commercialise. According to Ladele, Akinwale \& Oyelami (2016) through innovative engagement by an intermediary such as private extension services, successful market linkages between farmers and other stakeholders can be developed.

The relationship between the reliability of local extension service providers in enabling access to market information and banana commercialisation was found to be statistically significant This revealed that a local extension service provider was very reliable in enabling farmers to access marketing information. Therefore, this influenced farmer's decisions in banana commercialisation. The study observed that the sharing market information with other farmers and banana commercialisation was statistically significant implying that farmers sharing marketing information among themselves determines whether to commercialise banana farming. Most of the smallholder farmers (85.6\%) in Meru and Tharaka-Nithi Counties shared market information. The finding is in agreement with that of Kassa et al. (2017) who argued that to remedy marketing-related challenges, there is a need for capacity building among farmers about such aspects as the appropriateness of market information 
Creative Commons User License: CC BY-NC-ND

Abstracted by: EBSCOhost, Electronic Journals Service (EJS), Google Scholar, Journal Seek, Scientific Commons,

Food and Agricultural Organization (FAO), CABI and Scopus

http://eoi.citefactor.org/10.11226/v26i1
Journal of Agricultural Extension

Vol. 26 (1) January, 2022

ISSN(e): 24086851; ISSN(Print); 1119944X

http://journal.aesonnigeria.org

http://www.ajol.info/index.php/jae

Email: editorinchief@aesonnigeria.org

source and appropriate interpretation of such information to spur agricultural profitability. The authors further note that extension agents need to play the role of motivating the development of farmer marketing groups which are crucial in aggregating farm produce, price negotiation and farm input acquisition at lower prices.

Table 3: Extension-market linkages and banana commercialisation

\begin{tabular}{|c|c|c|c|c|}
\hline Variables & & Yes & $\chi^{2}$ & $\mathrm{df}$ \\
\hline Access to market information & Yes & 97.2 & $\begin{array}{l}25.713^{*} \\
\mathrm{a}\end{array}$ & 2 \\
\hline Type of information for banana & Types of market & 97.3 & $11.788^{*}$ & 4 \\
\hline marketing & $\begin{array}{l}\text { Market prices } \\
\text { Market Partners/linkages }\end{array}$ & $\begin{array}{l}95.3 \\
100\end{array}$ & a & \\
\hline A most useful type of information & Types of market & 100 & & \\
\hline on banana marketing & $\begin{array}{l}\text { Market prices } \\
\text { Market Partners/linkages }\end{array}$ & $\begin{array}{l}95.2 \\
100\end{array}$ & $3.378^{a}$ & 4 \\
\hline Sources of the Marketing & Extension officers & 100 & & \\
\hline intormatıon & Radio/Television & 100 & $8.577^{a}$ & 10 \\
\hline & Leaflets/pamphlets & 100 & & \\
\hline & Internet & 100 & & \\
\hline & Other Farmers & 93.2 & & \\
\hline & $\begin{array}{l}\text { Call/Text from trading } \\
\text { partners }\end{array}$ & 100 & & \\
\hline Reliability of local extension & Very reliable & 84.6 & & \\
\hline $\begin{array}{l}\text { service provider in enabling } \\
\text { access market information }\end{array}$ & $\begin{array}{l}\text { Reliable } \\
\text { Fairly }\end{array}$ & $\begin{array}{l}100 \\
94.7\end{array}$ & $18.270^{\mathrm{a}}$ & 8 \\
\hline & Not reliable & 100 & & \\
\hline & Don't Know & 94.6 & & \\
\hline Sharing market information with & Yes & 97.4 & & \\
\hline other farmers & $\begin{array}{l}\text { Large Extent } \\
\text { Moderate Extent } \\
\text { Low Extent }\end{array}$ & $\begin{array}{l}92.3 \\
100 \\
92.9\end{array}$ & $81.718^{\mathrm{a}}$ & 4 \\
\hline
\end{tabular}

\section{Relationship between Extension-Market linkages and Banana Commercialisation}

The pseudo $R 2$ of 0.0427 shows a good fit indicating that the model fitted the data well in Table 4. 
Table 4: Extension-market linkages and banana commercialisation

\begin{tabular}{|c|c|c|c|}
\hline Banana Commercialization & Coef. & Std. Err. & $\mathrm{t}$ \\
\hline Access to market information & 0 & (omitted) & \\
\hline $\begin{array}{l}\text { Type of information for banana } \\
\text { marketing }\end{array}$ & .1413929 & .0890825 & 1.59 \\
\hline $\begin{array}{l}\text { A most useful type of information on } \\
\text { banana marketing }\end{array}$ & .0506572 & .11232 & 0.45 \\
\hline Sources of the Marketing information & -0676939 & .0308509 & $-2.19^{\star}$ \\
\hline $\begin{array}{l}\text { Reliability of local extension service } \\
\text { provider in enabling access market } \\
\text { information }\end{array}$ & .0911385 & .043582 & $2.09^{*}$ \\
\hline $\begin{array}{l}\text { Sharing market information with other } \\
\text { farmers }\end{array}$ & -.047566 & .0275684 & -1.73 \\
\hline $\begin{array}{l}\text { The extent to share marketing } \\
\text { information }\end{array}$ & .0394808 & .059456 & 0.66 \\
\hline $\begin{array}{l}\text { Usefulness of marketing information in } \\
\text { commercializing banana business }\end{array}$ & .636157 & .18312 & $3.47^{\star}$ \\
\hline $\begin{array}{l}\text { cons } \\
\text { /sigma }\end{array}$ & $\begin{array}{l}.836306 \\
.7759169\end{array}$ & $\begin{array}{l}.4020831 \\
.0316358\end{array}$ & $2.08^{*}$ \\
\hline
\end{tabular}

Number of obs $=314 ;$ LR chi2(7) $=32.80 ;$ Prob $>$ chi2 $=0.0000$ Log likelihood $=-367.77944 ;$ Pseudo R2 $=0.0427$

Obs. summary: 0 left-censored observations

306 uncensored observations

8 right-censored observations at Banana Commercialisation $\sim d>=4$

Table 4 shows that sources of the marketing information (Coef. -.0676939) had a negative influence on farmers commercialising banana production. The findings imply that access to market information by farmer's leads to farmers commercialising their banana farming. The result shows that the reliability of local extension service providers in enabling farmer's access to market information (Coef. 0.037) had a positive influence on farmers commercialising banana production. The findings imply the more the local extension services were reliable in enabling farmers' access to market information, the more the farmers commercialise banana farming. The findings in Table 4 also show that the use of marketing information positively influenced the commercialisation of banana farming (Coef. 0.636157). The findings imply the market information was useful to farmers and this enabled them to commercialise banana production. 
Creative Commons User License: CC BY-NC-ND

Abstracted by: EBSCOhost, Electronic Journals Service (EJS),

Google Scholar, Journal Seek, Scientific Commons,

Food and Agricultural Organization (FAO), CABI and Scopus
Journal of Agricultural Extension

Vol. 26 (1) January, 2022

ISSN(e): 24086851; ISSN(Print); 1119944X

http://journal.aesonnigeria.org

http://www.ajol.info/index.php/jae

Email: editorinchief@aesonnigeria.org

The findings are consistent with those of William, Elias, Christophe, Jamie, and Vincent (2021), that mobile phones have a role in reaching a wider farmer audience, notably through radio, which is believed to be the most preferred communication channel. Through public-private partnerships, extension services in Uganda should be upgraded so that farmers are the primary actors in extended service delivery. Farmers can utilize phones to call service providers if they have an issue in this situation. Phone web systems, for example, can be a convenient way for farmers and extension workers to communicate. A multimedia messaging service (MMS) application can also assist farmers in taking a snapshot and sending it to an extension worker in the case of disease incidence and diagnosis, allowing for more specific and exact advisory service delivery. In the case of farmer learning groups, however, consultations with subject matter experts might be strengthened by group virtual (e.g., Zoom) meetings using a hands-free mobile phone application, where the group could ask questions directly to the technical person and receive rapid replies.

\section{Conclusion and Recommendations}

There was a relationship between extension-market linkages and banana commercialisation. Farmers having information or awareness on market information influenced their decision to commercialise or not commercialise banana farming. Government should come up with programmes where they buy bananas from the farmers, by doing so this will encourage farmers to commercialise bananas through farmer market linkages to help them increase their incomes.

\section{Acknowledgement}

We acknowledge the contributions of the University of Embu and the farmers who availed the useful information required during the research and the reviewers for enriching the article.

\section{References}

Dowsing, M., \& Cardey, S. (2020). Smallholder farmers' perspectives on Advisory Extension Services: A case study of the Gamo communities of southern Ethiopia. Social Sciences (Basel, Switzerland), 9(9), 159.

Farmbiz Africa (2019) Ready Market Excites over 2,200 Meru Farmers to Grow Bananas. Markets.HITS 2268.Meru. Kenya

Kassa, G., Yigezu, E., \& Alemayehu, D. (2017). Determinants of smallholder market participation among banana growers in bench Maji Zone, Southwest Ethiopia. International Journal of Agricultural Policy and Research, 5(11), 169-177.

Kenya National Bureau of Statistics (2019). Kenya Population and Housing Census 2019, Kenya.

Ladele, A. A., Akinwale, J. A., \& Oyelami, B. O. (2016). Linking maize farmers to market: A case study of private extension service in yewa north local government area of Ogun state, Nigeria. Journal of Agricultural Extension, 20(2), 118. 
Creative Commons User License: CC BY-NC-ND

Abstracted by: EBSCOhost, Electronic Journals Service (EJS), Google Scholar, Journal Seek, Scientific Commons,

Food and Agricultural Organization (FAO), CABI and Scopus

http://eoi.citefactor.org/10.11226/v26i1
Journal of Agricultural Extension

Vol. 26 (1) January, 2022

ISSN(e): 24086851; ISSN(Print); 1119944X

http://journal.aesonnigeria.org

http://www.ajol.info/index.php/jae

Email: editorinchief@aesonnigeria.org

Marcia, D H, Eduardo S. G. Mizubuti, Miguel D \& Charles P. (2016) Fusarium Wilt of Banana: Current Knowledge on Epidemiology and Research Needs Toward Sustainable Disease Management. Journal of Epidemiology and Management of Fusarium Wilt of Bananas 61 (3), 250-263.

Meru County Government. (2019, May 17). Meru county banana stakeholder's forum. https://meru.go.ke/content.php?com=31\&item $=578$

Muchesa, E., Nkosi, B. D., Zwane, E. M., \& van Niekerk, J. A. (2019). The role of extension support in A communal farmers' market system in mhondoro-mubaira, Zimbabwe. South African Journal of Agricultural Extension (SAJAE), 47(2). doi:10.17159/2413-3221/2019/v47n2a504

Mwendia, S A (2019) An investigation of the drivers of diversification to banana farming among households in Meru County, Kenya https://irlibrary.ku.ac.ke

Tinzaara, W., Stoian, D., Ocimati, W., Kikulwe, E., Otieno, G., \& Blomme, G. (2018). Challenges and opportunities for smallholders in banana value chains. Burleigh Dodds Series in Agricultural Science, 65-

90. https://doi.org/10.19103/as.2017.0020.10

William, T., Elias, O., Christophe, B., Jamie, A., \& Vincent, J. (2021). Mobile phone technology for increasing banana productivity among smallholder farmers in Uganda. Journal of Agricultural Extension and Rural Development, 13(1), 1-13. 